\title{
Enzymatic digestive activity and absorption efficiency in Tagelus dombeii upon Alexandrium catenella exposure
}

\author{
M. J. Fernández-Reiriz $\cdot$ J. M. Navarro • \\ B. A. Cisternas $\cdot$ J. M. F. Babarro $\cdot$ \\ U. Labarta
}

Received: 27 January 2012/Revised: 4 March 2013/Accepted: 5 March 2013/Published online: 19 March 2013

(c) Springer-Verlag Berlin Heidelberg and AWI 2013

\begin{abstract}
We analyzed absorption efficiency (AE) and digestive enzyme activity (amylase, cellulase complex, and laminarinase) of the infaunal bivalve Tagelus dombeii originating from two geographic sites, Corral-Valdivia and Melinka-Aysén, which have different long-term paralytic shellfish poisoning (PSP) exposure rates. We report the effects of past feeding history (origin) on $T$. dombeii exposed to a mixed diet containing the toxic dinoflagellate Alexandrium catenella and another dinoflagellate-free control diet over a 12-day period in the laboratory. Absorption efficiency values of $T$. dombeii individuals that experienced PSP exposure in their habitat (Melinka-Aysén) remained unchanged during exposure to toxic food in the laboratory. In contrast, T. dombeii from a non-PSP exposure field site (Corral-Valdivia) showed a significant reduction in $\mathrm{AE}$ with toxic exposure time. This study established that the amylase and cellulase complexes were the most important enzymes in the digestive glands of Tagelus from both sites. The temporal evolution of enzymatic activity under toxic diet was fitted to exponential (amylase and cellulase) and to a logarithmic (laminarinase) models. In all fits, we found significant effect of origin in the model parameters. At the beginning of the experiment,
\end{abstract}

Communicated by H.-D. Franke.

M. J. Fernández-Reiriz (ه) · J. M. F. Babarro · U. Labarta Instituto de Investigaciones Marinas, Consejo Superior de Investigaciones Científicas, Eduardo Cabello 6,

36208 Vigo, Spain

e-mail: mjreiriz@iim.csic.es

J. M. Navarro - B. A. Cisternas

Facultad de Ciencias, Instituto de Ciencias Marinas y

Limnológicas, Universidad Austral de Chile,

Casilla 567, Valdivia, Chile higher enzymatic activity was observed for clams from Corral-Valdivia. The amylase activity decreased with time exposure for individuals from Corral and increased for individuals from Melinka. Cellulase activity did not vary over time for clams from Corral, but increased for individuals from Melinka and laminarinase activity decreased over time for individuals from Corral and remained unchanged over time for Melinka. A feeding history of exposure to the dinoflagellate A. catenella was reflected in the digestive responses of both $T$. dombeii populations.

Keywords Alexandrium - Tagelus dombeii - Absorption efficiency · Enzymatic activity · Trophic regimen

\section{Introduction}

Tagelus dombeii (razor clam) is an infaunal species that inhabits soft sediments at a water depth of 1-13 m between the Tumbes region of northwestern Perú and Aysén in the southern Chile. Dense razor clam populations are farmed by traditional fisheries, and total landings have decreased from 7,294 $\mathrm{t}$ in 1995 to $3,248 \mathrm{t}$ in 2010 (SERNAPESCA 2010). Razor clam farming (T. dombeii) represents about $5 \%$ of benthic resources utilized in Chile. The two razor clam populations investigated here inhabit the subtidal shallow water, characterized by a sandy bottom. The T. dombeii population of Melinka-Aysén has been exposed to frequent PSP events in recent decades, while no PSP events have been recorded for Corral-Valdivia (Guzman and Campodonico 1978; Molinet et al. 2003).

Navarro et al. (2008) studied the feeding behavior of T. dombeii from intertidal and subtidal communities in Chile looking for a dual feeding strategy (suspension/ detritivoral). They concluded that $T$. dombeii is mainly a 
suspension feeder. Alexandrium catenella are harmful algae that produce paralytic shellfish poisoning (PSP) toxin, which can be fatal to humans and may be present at different concentrations in the diet of bivalves, zooplankton, crustaceans, and gastropods (Huss 2003). Shumway and Cucci (1987) studied the effects of the dinoflagellate Protogonyaulax tamarensis on the feeding behavior of bivalve mollusks. They noted that the animals exhibited valve closure and/or siphon retraction (Mya arenaria, Mytilus edulis, Geukensia demisa) as well as a reduced (M. arenaria, G. demisa) or increased (Ostrea edulis) clearance rates. In contrast, the latter authors also observed that two species, Modiolus modiolus and Spisula solidissima, were not affected by the toxic dinoflagellates.

Lassus et al. (2004) reported that the Pacific oyster Crassostrea gigas and the $M$. arenaria clam reduced their filtration activity when feeding on microalgae containing PSP toxins. Alexandrium catenella exposure is also known to have a negative impact on initial filtration and ingestion in Mytilus chilensis (Navarro and Contreras 2010). Exposure of bivalves to harmful microalgae can also affect their digestion and energy allocation. Li et al. (2002) assessed the effects of Alexandrium tamarense on the energy budget, quantified as scope for growth (SFG), of the mussel Perna viridis and the manila clam Ruditapes philippinarum and demonstrated that an increase in PSP burden was associated with a significant reduction in SFG in both clams and mussels, primarily because of decreases in absorption efficiency (AE). This effect can hypothetically be linked to modification of the digestive process as observed by Fernández-Reiriz et al. (2008) who studied trophic interactions between $M$. chilensis and the toxic dinoflagellate $A$. catenella over a 21-day period to determine the absorption kinetics of biochemical components and the enzymatic activity of the digestive gland (amylase, cellulase complex, laminarinase, and protease). Their study showed that $M$. chilensis was able to develop mechanisms that enable the use of toxic microalgae as a food source, despite the fact that its feeding and digestive processes were affected in the early days of contamination.

The digestive gland in bivalves plays an important role in the digestion and assimilation of nutrients. FernándezReiriz et al. (2001) and Labarta et al. (2002) established that investment in enzyme resources is one of the mechanisms used by bivalve mollusks to optimize energy gains when variations in food supplies occur. According to Galimany et al. (2008a, b, c) and Hégaret et al. (2009), the digestive gland is generally the organ most affected by PSP exposure. Thus, it appears pertinent to study the digestive process in the digestive gland of the razor clam T. dombeii.

The objective of this study was to determine the AE as well as the enzymatic activity of the digestive gland (amylase, cellulase complex, and laminarinase) in two razor clam $T$. dombeii populations with differing historical exposures to PSP toxins, when exposed to the toxic dinoflagellate A. catenella.

\section{Materials and methods}

\section{Experimental design}

Adult specimens of the razor clam $T$. dombeii ranging in shell length from 50 to $70 \mathrm{~mm}$ were collected from natural banks at Corral-Valdivia and Melinka-Aysén in 2010 (see Fig. 1). They were transported to the laboratory, where they were acclimated for 1 week at a temperature of $14{ }^{\circ} \mathrm{C}$ and a salinity of 30 practical salinity units (PSU). During this period, the clams were buried in aquarium tanks and continuously fed a diet containing $60 \%$ microalgae clone T-ISO and $40 \%$ inorganic sediment $(1.5 \mathrm{mg} / \mathrm{L})$ using a peristaltic pump. The laboratory conditions (i.e., temperature, salinity, food supply, and organic content of the diet) were set to follow the conditions of the animals' natural habitat. The tanks were constantly aerated, and the seawater was changed every $48 \mathrm{~h}$. Following the acclimation period, one group of clams was exposed to a mixed diet containing the toxic dinoflagellate $A$. catenella (proportions by weight: $50 \%$ A. catenella, $10 \%$ T-ISO, and $40 \%$ sediment) and another group was exposed to a dinoflagellate-free control diet $(60 \%$ T-ISO, $40 \%$ sediment) for 12 days. Given the large amount of laboratory analysis and large individual variability in the physiological responses of bivalves exposed to PSP (Navarro and Contreras 2010), four replicates (8-L tanks, temperature $14{ }^{\circ} \mathrm{C}$, salinity 30 PSU) containing 25 clams each were supplied with the toxic diet, whereas three replicates containing the same number of clams were supplied with the control diet (less variable responses). The forth toxic tank was included in the experiment as an extra to be used if necessary, but all the statistical analysis was conducted with three toxic and control aquaria. The clams were permanently buried in sediment collected from their natural habitats and given a daily allotment of food equal to $2 \%$ (measured, ca. $14 \mathrm{mg} /$ day) of the dry body weight of the experimental clams. We observed no significant differences ( $p$ value $>0.05$ ) in the daily amounts of food reaching each population, and the concentration of both diets was below the threshold of pseudofeces production. The diets were delivered continuously using a peristaltic pump. The monoclonal non-axenic A. catenella (strain ACC02) and clone T-ISO were cultivated following the method of Fernández-Reiriz et al. (2008). Toxicity was quantified using an electrophysiological test as described by Vélez et al. (2001), and a mean value was calculated from the test results of 15 samples. The toxic diet was prepared by mixing laboratory cultured $A$. catenella, T-ISO, and washed and ashed sediment. Samples of this diet were collected on 


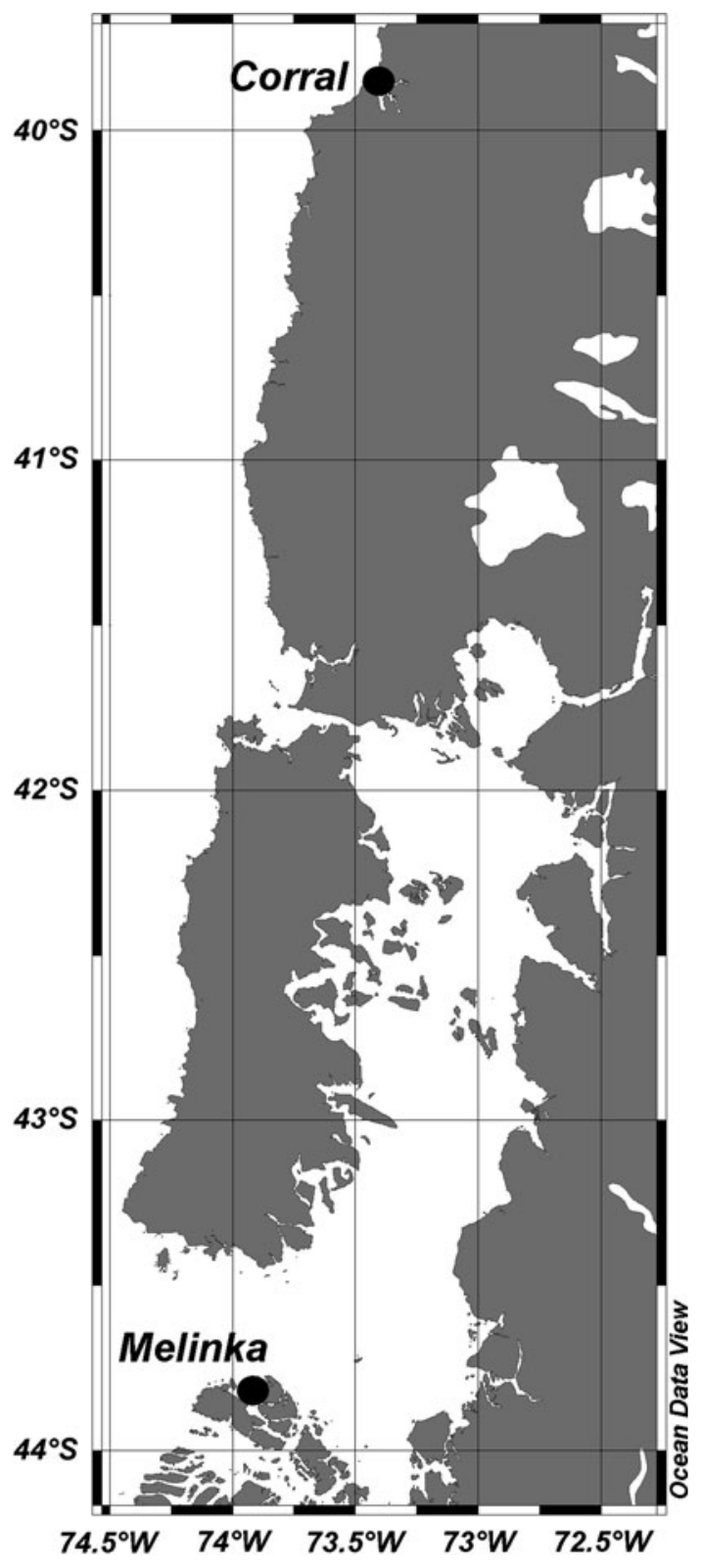

Fig. 1 Map of southern Chile showing habitat origin sites

pre-washed, ashed, and weighed Whatman GF/C glass fiber filters and rinsed with $0.5 \mathrm{M}$ ammonium formate. Subsequently, triplicate samples were taken for total matter (following oven-drying to a constant weight at $100{ }^{\circ} \mathrm{C}$ ) and organic matter (following ashing in a muffle furnace to a constant weight at $450{ }^{\circ} \mathrm{C}$ ). The digestive behavior, $\mathrm{AE}$, and enzymatic activity in the control samples and the individual exposed to the contaminated diet were monitored throughout the experiment $(0,2,5,8$, and 12 day).

\section{Absorption efficiency}

We estimated AE by determining the organic and inorganic content of the food and feces following the ratio method of
Conover (1966). Representative samples of each diet mixture (ca. $15 \mathrm{mg}$; three replicates) were collected during the experiment, and the AE was calculated for each specimen by collecting feces $(4-10 \mathrm{mg}$ ) from the top of the sediment using glass pipettes. Fecal pellets were separated from the sediment by careful observation under a stereoscope, and they were filtered through pre-ashed, pre-weighed Whatman GF/C filters in a manner similar to the diet mixture. Filters were rinsed with isotonic ammonium formate, dried to a constant weight at $100{ }^{\circ} \mathrm{C}(24 \mathrm{~h})$, and then weighed and combusted at $450{ }^{\circ} \mathrm{C}$ to a constant weight. The filters were weighed again to estimate the organic and inorganic fraction contained in the food and feces.

In vitro enzyme assays

Freeze-dried digestive glands dissected from the experimental animals were cold-homogenized in $0.01 \mathrm{M}$ phosphate-citrate buffer, about $10 \mathrm{mg} / \mathrm{mL}$ (containing $20 \mathrm{mM}$ $\mathrm{NaCl})$ at $\mathrm{pH}$ 6.9. The enzyme extracts were immediately centrifuged at $15,938 \times g$ for $20 \mathrm{~min}$, and the supernatant was used for in vitro enzyme assays following the methodology described by Ibarrola et al. (1996). The protein content within the clams' digestive extracts was determined as described by Lowry et al. (1951) using bovine serum albumin as the standard.

The substrate solutions (starch $1 \%$, carboxymethylcellulose $1 \%$, laminarin $0.4 \%$ ) were prepared with a $0.2 \mathrm{M}$ citrate-phosphate buffer containing $20 \mathrm{mM} \mathrm{NaCl}$ to the corresponding pre-established optimal $\mathrm{pH}$ of 6.5 for amylase, laminarinase, and cellulase complex. To follow the reaction, $0.5 \mathrm{~mL}$ of digestive extract and $0.5 \mathrm{~mL}$ of substrate solution were mixed and incubated at ambient temperature $\left(14{ }^{\circ} \mathrm{C}\right)$ in a circulating water bath for $30 \mathrm{~min}$. The concentration of the digestive extract and time interval for lineal release of endproduct were assessed relative to body mass (frozen and freeze-dried) and confirmed to be optimal according to preliminary studies (Fernández-Reiriz et al. 2001, 2008).

Carbohydrase activity (amylase, cellulase complex, and laminarinase) was determined using the Nelson-Somogyi method (Nelson 1944; Somogyi 1952) with a calibration curve established using maltose. In this work, the enzyme assays are expressed in terms of specific activity (sp) expressed as (mg end-product released)/(mg protein $\mathrm{h}$ ). To preclude digestive organ variability caused by weight differences, these weights were corrected to a standard-sized individual with a dry weight of $1,000 \mathrm{mg}$, following the formula

$Y_{\mathrm{s}}=\left(1,000 / W_{\mathrm{e}}\right)^{b} Y_{\mathrm{e}}$

where $Y_{\mathrm{s}}=$ dry weight of the standardized organ; $Y_{\mathrm{e}}=$ experimental dry weight of the organ; $W_{\mathrm{e}}=$ total dry weight of the experimental clam; $b=$ weight-specific 
exponent relating digestive organ weight to complete specimen weight $(b=0.7256$ and 0.8900 for the digestive gland of T. dombeii from Melinka and Corral, respectively).

Statistical analysis

In our experimental design, $\mathrm{AE}$ and enzymatic activity are measured repeatedly on each tank over time, that is, we have longitudinal data. Therefore, we should apply repeated measures analysis of variance (Quinn and Keough 2002), which, on contrast with classical ANOVA models, considers the temporal dependence among samples from the same tank. Three-way repeated-measures ANOVA (tank as random factor) was conducted to analyze the effects of diet (control and toxic), origin (Melinka and Corral), and time of exposure (TE) on the AE and enzymatic activity. When the temporal change in $\mathrm{AE}$ and enzymatic activity depended on the diet, that is, in case of significant interaction between diet and time and/or threeway interaction, the temporal pattern of individuals under control and toxic diets were analyzed separately. For each diet, we applied two-way repeated-measures ANOVA (tank as random factor) to test the effect of origin and TE on $\mathrm{AE}$ and enzymatic activity. When the effect of time was significant, we fitted the temporal change in $\mathrm{AE}$ and enzymatic activity and applied covariance analysis (ANCOVA) for comparison between origins. For each ANOVA conducted, normality and homoscedasticity were previously tested by Shapiro-Wilk and Levene tests. Statistical analysis was conducted using R 2.14.2 software (R Development Core Team 2011).

\section{Results}

Experimental diets

Total concentration of particulate material (TPM) did not differ significantly between the toxic $(1.99 \pm 0.06$ $\mathrm{mg} / \mathrm{L})$ and control $(1.95 \pm 0.19 \mathrm{mg} / \mathrm{L})$ diet groups ( $p$ value $>0.05$ ). Moreover, organic content also did not differ significantly ( $p$ value $>0.05$ ) between the toxic diet group $(1.21 \pm 0.05 \mathrm{mg} / \mathrm{L}, 61 \%)$ and the control diet group $(1.08 \pm 0.09 \mathrm{mg} / \mathrm{L}, 56 \%)$. The mean toxic content of A. catenella cells (strain ACCO2) was $10.31 \pm 0.91 \mathrm{fmol}$ STXeq cell.

\section{Absorption efficiency}

Table 1 illustrates the $\mathrm{AE}$ in $T$. dombeii for each diet, origin, and TE. Table 2 shows the three-way repeated-measures ANOVA for AE, the between-group test indicates that the effects of diet, origin, and interaction between them were
Table 1 Descriptive analysis (mean, SD) of AE by diet, origin, and TE

\begin{tabular}{|c|c|c|c|c|c|c|c|c|}
\hline \multirow[t]{3}{*}{ TE } & \multicolumn{4}{|c|}{ Corral-Valdivia } & \multicolumn{4}{|c|}{ Melinka-Aysén } \\
\hline & \multicolumn{2}{|c|}{ Control } & \multicolumn{2}{|l|}{ Toxic } & \multicolumn{2}{|c|}{ Control } & \multicolumn{2}{|l|}{ Toxic } \\
\hline & Mean & SD & Mean & SD & Mean & SD & Mean & SD \\
\hline \multicolumn{9}{|l|}{$\mathrm{AE}$} \\
\hline 0 & 75.89 & 2.88 & 75.03 & 10.36 & 78.34 & 0.13 & 76.31 & 1.41 \\
\hline 2 & 75.60 & 1.97 & 74.01 & 8.73 & 78.04 & 2.06 & 77.99 & 0.79 \\
\hline 5 & 73.72 & 2.14 & 66.36 & 9.02 & 79.85 & 2.43 & 78.45 & 3.23 \\
\hline 8 & 72.00 & 3.00 & 52.07 & 5.01 & 77.12 & 3.65 & 74.18 & 3.62 \\
\hline 12 & 73.67 & 4.51 & 40.64 & 8.96 & 77.56 & 6.76 & 74.25 & 1.09 \\
\hline
\end{tabular}

Table 2 Three-way repeated-measures ANOVA for AE

\begin{tabular}{lcccll}
\hline & $d f$ & Sum sq & Mean sq & $F$ & $p$ value \\
\hline Error: tank & & & & & \\
$\quad$ Diet & 1 & 788.2 & 788.2 & 50.2 & $0.0001^{* * *}$ \\
$\quad$ Origin & 1 & $1,300.2$ & $1,300.2$ & 82.82 & $1.7 \times 10^{-05 * * *}$ \\
Diet:origin & 1 & 422 & 422 & 26.88 & $0.0008^{* * *}$ \\
$\quad$ Residuals & 8 & 125.6 & 15.7 & & \\
Error: within & & & & & \\
TE & 4 & $1,006.8$ & 251.71 & 8.951 & $5.7 \times 10^{-05 * * *}$ \\
TE:diet & 4 & 660.1 & 165.03 & 5.869 & $0.0012^{* *}$ \\
TE:origin & 4 & 601.1 & 150.28 & 5.344 & $0.0021^{* *}$ \\
TE:diet:origin & 4 & 486.6 & 121.66 & 4.327 & $0.0066^{* *}$ \\
Residuals & 32 & 899.8 & 28.12 & & \\
\hline
\end{tabular}

$* * p<0.01$

$* * * p<0.001$

significant. The within- tank test shows a significant TE effect, interaction between TE and both group factors (diet and origin), and three-way interaction.

For the control diet, we only found significant differences between origins (two-way repeated-measures ANOVA, $p$ value $=0.0139$ ). Thus, $\mathrm{AE}$ for $T$. dombeii under control diet did not vary over time and was lower for individuals from Corral $(74.18 \%)$ than for individuals from Melinka (78.18\%).

For individuals subjected to toxic diet, significant effects of time, origin, and interaction between them (two-way repeated-measures ANOVA, $p$ value $<0.01$ ) were found. We fitted the temporal evolution of AE by a linear model (Fig. 2). Comparison between origins (ANCOVA, Table 7) did not find differences at the beginning of the experiment ( $t$ test intercept, $p$ value $=0.903$ ), but found differences between slopes: While toxic exposure caused a decrease in $\mathrm{AE}$ for clams from Corral $(\mathrm{AE}=78.19-3.068 \mathrm{TE}$; Adj $R^{2}=0.738 ; p$ value $\left.=2.5 \mathrm{e}^{-5}\right)$, AE did not vary over time $\left(\mathrm{AE}=77.76-0.282 \mathrm{TE} ;\right.$ Adj $R^{2}=0.1504 ; p$ value $=$ 0.0849) for clams from Melinka. 

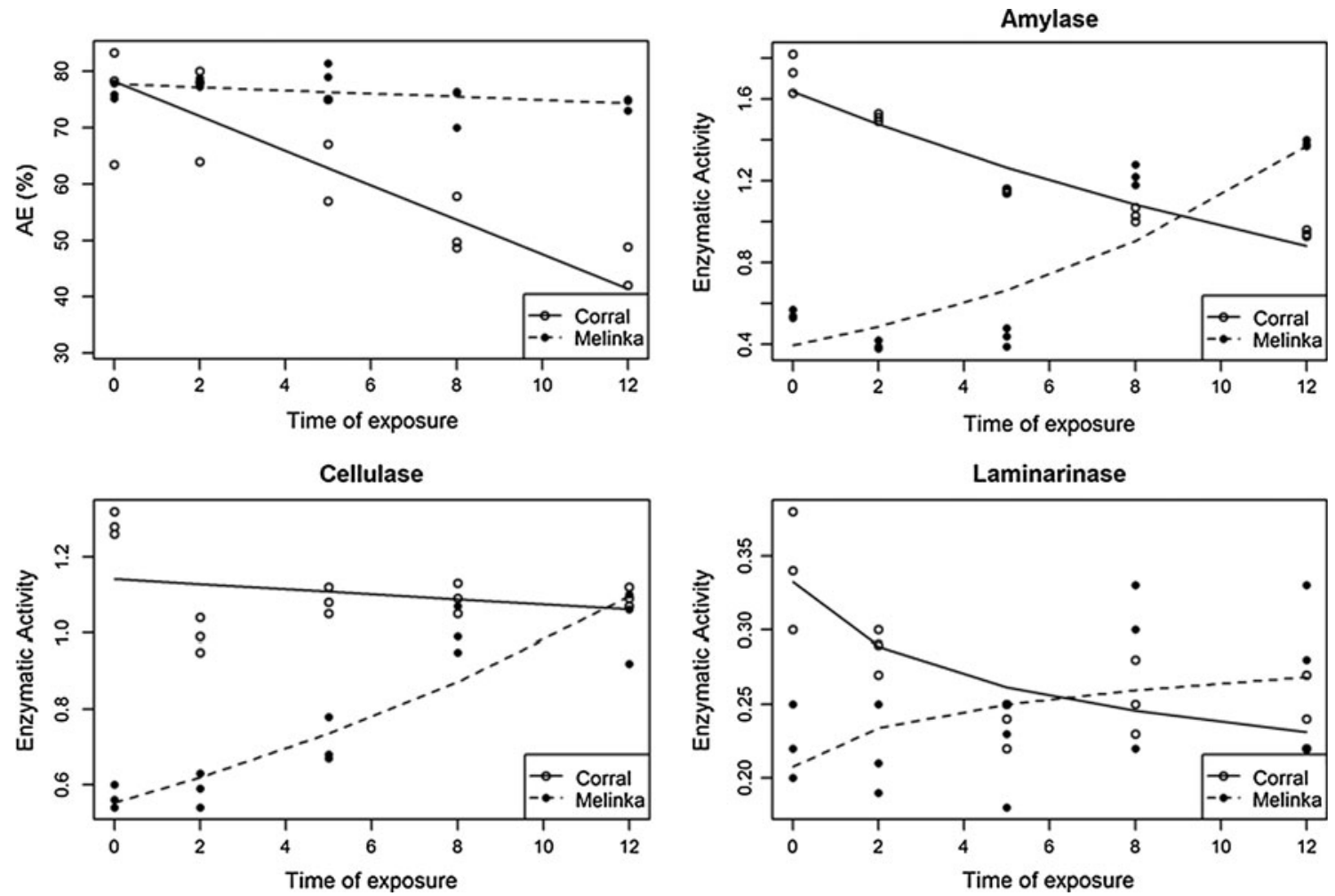

Fig. 2 Fist of temporal evolution of AE and carbohydrase activities for T. dombeii individuals subjected to toxic diet

Table 3 Descriptive analysis (mean, SD) of specific enzymatic activity by diet, origin, and $\mathrm{TE}$

\begin{tabular}{|c|c|c|c|c|c|c|c|c|}
\hline \multirow[t]{3}{*}{$\mathrm{TE}$} & \multicolumn{4}{|c|}{ Corral-Valdivia } & \multicolumn{4}{|c|}{ Melinka-Aysén } \\
\hline & \multicolumn{2}{|c|}{ Control } & \multicolumn{2}{|l|}{ Toxic } & \multicolumn{2}{|c|}{ Control } & \multicolumn{2}{|l|}{ Toxic } \\
\hline & Mean & $\mathrm{SD}$ & Mean & $\mathrm{SD}$ & Mean & SD & Mean & SD \\
\hline \multicolumn{9}{|c|}{ Amylase } \\
\hline 0 & 1.16 & 0.04 & 1.73 & 0.10 & 0.63 & 0.11 & 0.55 & 0.02 \\
\hline 2 & 1.17 & 0.02 & 1.51 & 0.02 & 0.67 & 0.02 & 0.40 & 0.02 \\
\hline 5 & 1.19 & 0.04 & 1.15 & 0.01 & 0.64 & 0.06 & 0.44 & 0.05 \\
\hline 8 & 1.16 & 0.04 & 1.03 & 0.04 & 0.66 & 0.03 & 1.23 & 0.05 \\
\hline 12 & 1.16 & 0.03 & 0.94 & 0.02 & 0.64 & 0.05 & 1.38 & 0.02 \\
\hline \multicolumn{9}{|c|}{ Cellulase } \\
\hline 0 & 1.02 & 0.04 & 1.29 & 0.03 & 0.54 & 0.03 & 0.57 & 0.03 \\
\hline 2 & 1.04 & 0.03 & 0.99 & 0.05 & 0.54 & 0.06 & 0.59 & 0.05 \\
\hline 5 & 1.00 & 0.06 & 1.08 & 0.04 & 0.53 & 0.06 & 0.71 & 0.06 \\
\hline 8 & 1.01 & 0.04 & 1.09 & 0.04 & 0.53 & 0.07 & 1.00 & 0.06 \\
\hline 12 & 1.00 & 0.03 & 1.09 & 0.03 & 0.58 & 0.01 & 1.03 & 0.09 \\
\hline \multicolumn{9}{|c|}{ Laminarinase } \\
\hline 0 & 0.25 & 0.03 & 0.34 & 0.04 & 0.25 & 0.05 & 0.22 & 0.03 \\
\hline 2 & 0.24 & 0.03 & 0.29 & 0.02 & 0.20 & 0.05 & 0.22 & 0.03 \\
\hline 5 & 0.24 & 0.02 & 0.24 & 0.02 & 0.21 & 0.02 & 0.22 & 0.04 \\
\hline 8 & 0.27 & 0.01 & 0.25 & 0.03 & 0.26 & 0.03 & 0.28 & 0.06 \\
\hline 12 & 0.29 & 0.03 & 0.24 & 0.03 & 0.26 & 0.01 & 0.28 & 0.06 \\
\hline
\end{tabular}

Enzymatic activity: amylase, cellulase, and laminarinase

Dry weight was higher $(p$ value $<0.05)$ in $T$. dombeii individuals from Melinka-Aysén $(\sim 850 \mathrm{mg})$ compared to those from Corral-Valdivia ( $600 \mathrm{mg}$ ). Protein levels did not differ between the diet groups ( $p$ value $>0.05$ ), with dry weight values close to $20 \%$ for both the toxic and control groups.

Table 3 illustrates the specific enzymatic activity (sp) in T. dombeii for each diet, origin, and TE. Tables 4, 5, and 6 show the three-way repeated-measures ANOVA for the carbohydrase activities. Between-group comparison shows significant effects of diet, origin, and interaction between them for amylase and cellulase activity, while for laminarinase we only found significant effect of origin. The within tanks test shows significant TE effect, interaction between TE and both group factors, and three-way interaction for amylase and cellulase, while for laminarinase there was no interaction between TE and diet ( $p$ value $=0.3463$ )

For $T$. dombeii individuals under control diet, the twoway repeated-measures ANOVA found that enzymatic activity of amylase and cellulase was higher for clams from Corral $\left(p\right.$ value $=4.23 \times 10^{-7}$ and $1.01 \times 10^{-5}$, respectively) and did not vary over time ( $p$ values $>0.1$ for TE effect and interaction between time and origin). On the 
Table 4 Three-way repeated-measures ANOVA for amylase

\begin{tabular}{lrllrl}
\hline & $d f$ & Sum sq & Mean sq & \multicolumn{1}{l}{$l$} & \multicolumn{1}{l}{$p$ value } \\
\hline Error: tank & & & & & \\
$\quad$ Diet & 1 & 0.248 & 0.248 & 418.53 & $3.4 \times 10^{-08 * * *}$ \\
Origin & 1 & 3.69 & 3.69 & $6,219.51$ & $7.5 \times 10^{-13} * * *$ \\
Diet:origin & 1 & 0.007 & 0.007 & 11.51 & $0.0095^{* *}$ \\
$\quad$ Residuals & 8 & 0.005 & 0.001 & & \\
Error: within & & & & & \\
TE & 4 & 0.273 & 0.0683 & 28.03 & $4.7 \times 10^{-10_{* * *}}$ \\
TE:diet & 4 & 0.3353 & 0.0838 & 34.42 & $3.6 \times 10^{-11}$ *** \\
TE:origin & 4 & 1.7074 & 0.4269 & 175.3 & $<2 \times 10^{-05 * * *}$ \\
TE:diet:origin & 4 & 1.6626 & 0.4156 & 170.69 & $<2 \times 10^{-16 * * *}$ \\
Residuals & 32 & 0.0779 & 0.0024 & & \\
\hline
\end{tabular}

$* * p<0.01$

$* * * p<0.001$

Table 5 Three-way repeated-measures ANOVA for cellulase

\begin{tabular}{lrllrl}
\hline & $d f$ & Sum sq & Mean sq & \multicolumn{1}{l}{$p$} & \multicolumn{1}{l}{$p$ value } \\
\hline Error: tank & & & & & \\
$\quad$ Diet & 1 & 0.4067 & 0.4067 & 245.76 & $2.7 \times 10^{-07 * * *}$ \\
Origin & 1 & 2.408 & 2.408 & $1,454.99$ & $2.5 \times 10^{-10_{* * *}}$ \\
Diet:origin & 1 & 0.0735 & 0.0735 & 44.41 & $0.0002^{* * *}$ \\
$\quad$ Residuals & 8 & 0.0132 & 0.0017 & & \\
Error: within & & & & & \\
TE & 4 & 0.1484 & 0.0371 & 15.11 & $4.9 \times 10^{-07 * * *}$ \\
TE:diet & 4 & 0.1556 & 0.0389 & 15.84 & $3.0 \times 10^{-07 * * *}$ \\
TE:origin & 4 & 0.2379 & 0.0595 & 24.22 & $2.7 \times 10^{-09} * * *$ \\
TE:diet:origin & 4 & 0.1994 & 0.0499 & 20.3 & $2.1 \times 10^{-08 * * *}$ \\
Residuals & 32 & 0.0786 & 0.0025 & & \\
\hline
\end{tabular}

$* * * p<0.001$

other hand, we found significant effect of TE on laminarinase activity ( $p$ value $=0.0108$ ), which increased over time (Melinka: $\mathrm{sp}=0.2353+0.0042 \mathrm{TE}$, Adj $R^{2}=0.2113$, $p$ value $=0.0495$; Corral: $\mathrm{sp}=0.2209+0.0029 \mathrm{TE}$, Adj $R^{2}=0.343, p$ value $=0.0128$ )

For T. dombeii individuals under toxic diet, the two-way repeated-measures ANOVA found significant effects of time, origin, and interaction between them ( $p$ value $<0.001$ ) for amylase and cellulose activity, as well as significant effect of time and interaction between time and origin for laminarinase $(p$ value $<0.05$ ). The temporal evolution of specific enzymatic activity (sp) was fitted by exponential models for amylase and cellulase and by a logarithmic model for laminarinase. In all three fits, we found significant effect of origin in the model parameters (ANCOVA, Table 7, $p$ value $<0.001)$. At the beginning of the experiment, higher enzymatic activity was observed for clams from Corral (Table 3; Fig. 2). The amylase activity decreased with TE for individuals from Corral $(b=-0.0516)$ and increased for
Table 6 Three-way repeated-measures ANOVA for laminarinase

\begin{tabular}{lrrlrl}
\hline & $d f$ & Sum sq & Mean sq & \multicolumn{1}{l}{$F$} & $p$ value \\
\hline Error: tank & & & & & \\
$\quad$ Diet & 1 & 0.0017 & 0.0017 & 1.903 & 0.205 \\
$\quad$ Origin & 1 & 0.0091 & 0.0091 & 10.178 & $0.0128^{*}$ \\
Diet:origin & 1 & 0.0002 & 0.0002 & 0.186 & 0.6778 \\
Residuals & 8 & 0.0072 & 0.0009 & & \\
Error: within & & & & & \\
TE & 4 & 0.0185 & 0.0046 & 4.321 & $0.0066^{* *}$ \\
TE:diet & 4 & 0.0050 & 0.0012 & 1.161 & 0.3463 \\
TE:origin & 4 & 0.0113 & 0.0028 & 2.634 & 0.0523 \\
TE:diet:origin & 4 & 0.0159 & 0.0040 & 3.713 & $0.0136^{*}$ \\
Residuals & 32 & 0.0343 & 0.0011 & & \\
\hline$* p<0.05$ & & & & & \\
$* * p<0.01$ & & & & &
\end{tabular}

Melinka ( $b=0.1032)$. Cellulase activity did not vary over time for clams from Corral (Adj $R^{2}=0.0167$, $p$ value $=0.28)$ and increased for individuals from Melinka $(b=0.0569)$. Finally, laminarinase activity decreased over time for individuals from Corral $(b=-0.0393)$ and did not vary over time for Melinka (Adj $R^{2}=0.1597$, $p$ value $=0.078)$.

Amylase sp (toxic diet):

Melinka: $\mathrm{sp}=0.3968 \mathrm{e}^{0.1032 \mathrm{TE}}$,

Adj $R^{2}=0.6708, p$ value $=0.0001$.

Corral: $\mathrm{sp}=1.6366 \mathrm{e}^{-0.0516 \mathrm{TE}}$

Adj $R^{2}=0.9093, p$ value $=2.3 \times 10^{-08}$.

Cellulase sp (toxic diet):

Melinka: $\mathrm{sp}=0.5532 \mathrm{e}^{0.0569 \mathrm{TE}}$,

Adj $R^{2}=0.8495, p$ value $=6.4 \times 10^{-07}$.

Corral: $\mathrm{sp}=1.1419 \mathrm{e}^{-0.0061 \mathrm{TE}}$,

Adj $R^{2}=0.0167, p$ value $=0.28$.

Laminarinase sp (control diet):

Melinka: $\mathrm{sp}=0.2353+0.0042 \mathrm{TE}$,

Adj $R^{2}=0.2113, p$ value $=0.0495$.

Corral: $\mathrm{sp}=0.2209+0.0029 \mathrm{TE}$,

Adj $R^{2}=0.343, p$ value $=0.0128$.

Laminarinase sp (toxic diet):

Melinka: $\mathrm{sp}=0.2078+0.0236 \ln (\mathrm{TE}+1)$,

Adj $R^{2}=0.1597, p$ value $=0.078$.

Corral: $\mathrm{sp}=0.3322-0.0393 \ln (\mathrm{TE}+1)$,

Adj $R^{2}=0.6458, p$ value $=0.0002$. 


\section{Discussion}

Bivalve mollusks have developed great flexibility in their feeding regimen in response to changes in quantity and quality of seston, enabling them to optimize their energy gains (Velasco and Navarro 2002; Labarta et al. 2002). Bayne et al. (1989) suggested that changes in enzymatic activity can also be a key factor governing short-term digestive responses. However, few studies have established the relationship between digestive enzyme activity and the nutritional conditions in which bivalves live (Ibarrola et al. 2012). Fernández-Reiriz et al. (2001) and Labarta et al. (2002) showed that investment in enzymatic resources is one of the mechanisms used by M. chilensis and Mulinia edulis to optimize energy gain concurrent with variations in feeding.

The physiological processes of bivalves can be affected by consumption of toxic algae (Gainey and Shumway 1988). Li et al. (2002) studied the effect of A. tamarense (PSP toxins) on the energy budget (SFG) and growth of the clam $R$. philippinarum and the mussel $P$. viridis. They found that changes in PSP toxin levels affected clearance rate in clams, but not in mussels, and attributed this dissociation to poisoning of cilia in clams. Meanwhile, they observed that AE decreased in both species with diets containing PSP toxins, which reduced SFG. According to Li et al. (2002), bivalves fed with A. tamarense produced abnormal feces mixed with white mucus, suggesting the presence of a digestive system disorder affecting AE. Similar observations have been made by Navarro and Contreras (2010) for M. chilensis, for which the lowest AE values occurred during the first day of exposure to a toxic diet, and that nadir coincided with the production of less compact, yellowish-colored feces.

In our study, we observed a drop in the AE of T. dombeii upon toxic exposure of the Corral-Valdivia population not previously exposed to PSP in their original site (Molinet et al. 2003). Such a drop in AE could be related to alterations in digestive processes, as described by Wikfors and Smolowitz (1995) for the eastern oyster (Crassostrea virginica) fed with a toxic diet. According to Bayne et al. (1989), the digestive process of mussels requires prolonged periods of acclimation in response to variations in diet or feeding versus fasting regimens, as observed in other mollusks (Widdows et al. 1979; Smolowitz and Shumway 1997).

Our study showed a higher level of amylase and cellulase activity in the digestive gland of $T$. dombeii originally from Corral-Valdivia compared with the activities observed for individuals from Melinka-Aysén. This higher carbohydrase activity in $T$. dombeii from Corral-Valdivia might be related to their original habitat which is characterized by a high amount of continental runoff from the Valdivia River carrying high particulate loads. Additionally, there is an abundance of macroalgae (Lessonia sp. and Durvillea sp.) in the exposed coastal zone where, nonetheless, there are no SP-producing microalgae present (Molinet et al. 2003). Our findings are in agreement with the work of Teo and Sabapathy (1990), who established that the high variability in digestive enzymes in bivalves may be due to differences in diet, since detritus particles originating from vascular plants and green algae contain starch and cellulose, whereas those from brown algae contain laminarin and cellulose. Brock et al. (1986) report that live particles also differ in the amount of carbohydrates that constitute them: Dinoflagellates and green algae contain starch and cellulose whereas cyanobacteria contain starch, and diatoms contain laminarin. Ibarrola et al. (1996) stated that cellulase activity is essential for nutrient acquisition when food is composed of cellulose walls, since the cellulase complex liberates organic compounds that occur naturally in cellulose walls.

According to Brock et al. (1986), the enzyme production can be regulated by external factors such as food availability and composition so the response observed for laminarinase activity of Tagelus fed with control diets (see Table 7) can be derived from control diet composition (60\% T-ISO). These algae contain laminarin as the main carbohydrate (Robert et al. 1994). Ibarrola et al. (2012) recently stated that the efficient utilization of the complex mix of carbohydrates present in natural diets requires an appropriate combination of digestive enzymes. Accordingly, reported interspecific differences in the composition of the pool of carbohydrases likely reflect microhabitat variability in the organic composition of suspensions that are available to the organisms' alimentary systems.
Table 7 Covariance analysis (ANCOVA) comparing regression fits for $\mathrm{AE}$ and carbohydrase activities between origins

\begin{tabular}{|c|c|c|c|c|c|}
\hline & \multirow[t]{2}{*}{ Model } & \multicolumn{2}{|l|}{ Intercept } & \multicolumn{2}{|l|}{$\mathrm{TE}$} \\
\hline & & $T$ value & $p$ value & $T$ value & $p$ value \\
\hline $\mathrm{AE}$ & $\mathrm{AE}^{*} \mathrm{a}+\mathrm{bTE}$ & -0.123 & 0.903 & 5.510 & $8.8 \times 10^{-06}$ \\
\hline Amylase & $\mathrm{sp}=\mathrm{a} \mathrm{e}^{\mathrm{bTE}}$ & -10.561 & $6.7 \times 10^{-11}$ & 7.943 & $2.0 \times 10^{-08}$ \\
\hline Cellulase & $\mathrm{sp}=\mathrm{ae}^{\mathrm{bTE}}$ & -12.537 & $1.6 \times 10^{-12}$ & 7.504 & $5.8 \times 10^{-08}$ \\
\hline \multicolumn{6}{|c|}{ Laminarinase } \\
\hline Control & $\mathrm{sp}=\mathrm{a}+\mathrm{bTE}$ & 0.785 & 0.439 & 0.484 & 0.633 \\
\hline Toxic & $\mathrm{sp}=\mathrm{a}-\mathrm{b} \ln \mathrm{TE}$ & -4.814 & $5.5 \times 10^{-05}$ & 4.336 & 0.0002 \\
\hline
\end{tabular}


Similar to clams fed with the control diet, amylase and cellulase complex were the most active enzymes in the digestive glands of $T$. dombeii fed toxic algae, while laminarinase activity remained lower than the activities of the other enzymes. This finding agrees with Brock and Kennedy (1992) who reported high laminarinase levels in style extracts of $C$. virginica, whereas low laminarinase activity was reported in oyster diverticula extracts (Brock et al. 1986).

Tagelus dombeii from Melinka-Aysén, which are adapted to toxic PSP exposure, increased their enzymatic activity with TE to toxic diet. Similar to what has been shown for mollusks like $M$. chilensis, individuals with a history of toxic food exposure likely developed mechanisms that enabled them to use toxic microalgae as a food source, despite any initial negative feeding and digestive effects (Fernández-Reiriz et al. 2008). This phenomenon can be considered an example of acclimation-a form of ecological memory that enables nutrient extraction from alternative, even toxic, food sources. The observed ability of $T$. dombeii to modify enzymatic expenditures and achieve constant or high $\mathrm{AE}$ in the presence of toxic A. catenella in the laboratory suggests that there is long-term adaptation to PSP toxins in the field. Moreover, toxin-naïve individuals (i.e., the Corral-Valdivia population) were unable to obtain any benefit from toxin exposure within the experimental time period and suffered a continued $\mathrm{AE}$ deficiency that could eventually weaken their energy status.

Acknowledgments We wish to thank Beatriz Gonzalez, Lourdes Nieto, Katerina Gonzalez, and Jorge López for technical assistance and Isabel Fuentes for statistical analyses. This study was supported by a research grant to JMN (FONDECYT 1080127).

\section{References}

Bayne BL, Hawkins AJS, Navarro E, Iglesias IP (1989) Effects of seston concentration of feeding, digestion and growth in the mussel Mytilus edulis. Mar Ecol Progr Ser 55:47-59

Brock V, Kennedy VS (1992) Quantitative analysis of crystalline style carbohydrases in five suspension-and deposit-feeding bivalves. J Exp Mar Biol Ecol 159:51-58

Brock V, Kennedy VS, Brock A (1986) Temperature dependency of carbohydrase activity in the hepatopancreas of thirteen estuarine and coastal bivalve species from the North American east coast. J Exp Mar Biol Ecol 103:87-101

Conover RJ (1966) Assimilation of organic matter by zooplankton. Limnol Oceanogr 11:338-345

Fernández-Reiriz MJ, Labarta U, Navarro JM, Velasco A (2001) Enzymatic digestive activity in Mytilus chilensis (Hupé 1954) in response to food regimes and past feeding history. J Comp Physiol B 171:449-456

Fernández-Reiriz MJ, Navarro JM, Contreras AM, Labarta U (2008) Trophic interactions between the toxic dinoflagellate Alexandrium catenella and Mytilus chilensis: feeding and digestive behavior to long-term exposure. Aquat Toxicol 87:245-251
Gainey LF, Shumway SE (1988) A compendium of the responses of bivalve mollusks to toxic dinoflagellates. J Shellfish Res 7:626-628

Galimany E, Sunila I, Hégaret H, Ramón M, Wikfors GH (2008a) Experimental exposure of the blue mussel (Mytilus edulis, L.) to the toxic dinoflagellate Alexandrium fundyense: histopathology, immune responses, and recovery. Harmful Algae 7:702-711

Galimany E, Sunila I, Hégaret H, Ramón M, Wikfors GH (2008b) Pathology and immune response of the blue mussel (Mytilus edulis, L.) after an exposure to the harmful dinoflagellate Prorocentrum minimum. Harmful Algae 7:630-638

Galimany E, Place AR, Ramón M, Jutson M, Pipe RK (2008c) The effects of feeding Karlodinium veneficum (PLY\#103; Gymnodinium veneficum Ballantine) to the blue mussel Mytilus edulis. Harmful Algae 7:91-98

Guzman L, Campodonico I (1978) Marea Roja en Chile. Interciencia 3:144-151

Hégaret H, da Silva P, Sunila I, Dixon MS, Alix J, Shumway SE, Wikfors GH, Soudant P (2009) Perkinsosis in the Manila clam Ruditapes philippinarum affects responses to the harmful-alga, Prorocentrum minimum. J Exp Mar Biol Ecol 371:112-120

Huss HH (2003) Aquatic biotoxins. Chapter 5.1.5. In: Huss HH, Ababouch L, Gram L (eds) Assessment and management of seafood safety and quality. FAO Fisheries Technical Paper, p 239

Ibarrola I, Iglesias JIP, Navarro E (1996) Differential absorption of biochemical components in the diet of the cockle Cerastoderma edule: enzymatic responses to variations in seston composition. Can J Zool 74:1887-1897

Ibarrola I, Arambalza U, Navarro J, Urrutia MB, Navarro E (2012) Allometric relationship in feeding and digestion in the Chilean mytilids Mytilus chilensis (Hupé), Choromytilus chorus (Molina) and Aulacomya ater (Molina): a comparative study. J Exp Mar Biol Ecol 426-427:18-27

Labarta U, Fernández-Reiriz MJ, Navarro JM, Velasco A (2002) Enzymatic digestive activity in epifaunal (Mytilus chilensis) and infaunal (Mulinia edulis) bivalves in response to changes in food regimes in a natural environment. Mar Biol 140:669-676

Lassus P, Baron P, Garen P, Truquet P, Masselin P, Bardouil M, Leguay D, Amzil Z (2004) Paralytic shellfish poison outbreaks in the Penze estuary: environmental factors affecting toxin uptake in the oyster, Crassostrea gigas. Aquat Living Resour 17:207-214

Li SC, Wang WX, Hsieh DPF (2002) Effects of toxic dinoflagellate Alexandrium tamarense on the energy budgets and growth of two marine bivalves. Mar Environ Res 53:145-160

Lowry OH, Rosebrough NJ, Fair AL (1951) Protein measurement with the Folin-phenol reagent. J Biol Chem 193:265-275

Molinet C, Lafon A, Lembeye G, Moreno A (2003) Spatial and temporal distribution patters of blooms of Alexandrium catenella (Whedon \& Kofoid) Balech 1985, on inland seas of northwest Patagonia, Chile. Rev Chil Hist Nat 76:1-15

Navarro JM, Contreras AM (2010) An integrative response by Mytilus chilensis to the toxic dinoflagellate Alexandrium catenella. Mar Biol 157:375-380

Navarro JM, Contreras AM, Chaparro OR (2008) Short-term feeding response of the mussel Mytilus chilensis exposed to diets containing the toxic dinoflagellate Alexandrium catenella. Rev Chil Hist Nat 81:41-49

Nelson N (1944) A photometric adaptation of the Somogyi method for the determination of glucose. J Biol Chem 153:375-380

Quinn GP, Keough MJ (2002) Experimental design and data analysis for biologists. Cambridge University Press, Cambridge

R Development Core Team (2011) R: a language and environment for statistical computing. R Foundation for Statistical Computing, Vienna, Austria. ISBN 3-900051-07-0. http://www.R-project.org/ 
Robert R, Moal J, Campillo MJ, Daniel JY (1994) The food value of starch rich flagellates for Pecten maximus (Linné) larvae. Preliminary results. Haliotis 23:169-171

Servicio Nacional de Pesca (SERNAPESCA) (2010) Anuario Estadístico de Pesca. Santiago, Chile, p 58

Shumway SE, Cucci TL (1987) The effects of the toxic dinoflagellate Protogonyaulax tamarensis on the feeding and behavior of bivalve mollusks. Aquat Toxicol 10:9-27

Smolowitz R, Shumway SE (1997) Possible cytotoxic effects of the dinoflagellate, Gyrodinium aureolum, on juvenile bivalve mollusks. Aquac Int 5:291-300

Somogyi M (1952) Notes on sugar determination. J Biol Chem 195:19-23

Teo LH, Sabapathy U (1990) Preliminary report on the digestive enzymes present in the digestive gland of Perna viridis. Mar Biol 106:403-407
Velasco LA, Navarro JM (2002) Feeding physiology of infaunal (Mulinia edulis) and epifaunal (Mytilus chilensis) bivalves under a wide range of concentration and quality of seston. Mar Ecol Prog Ser 240:143-155

Vélez P, Sierralta J, Alcayaga C, Fonseca M, Loyola H, Johns DC, Tomaselli GF, Suárez-Isla BA (2001) A functional assay for paralytic shellfish toxins that uses recombinant sodium channels. Toxicon 39:929-935

Widdows J, Moore MN, Lowe DM, Salkeld PN (1979) Some effects of the dinoflagellate bloom (Gyrodinium aureolum) on the mussel, Mytilus edulis. J Mar Biol Assoc UK 59:522-524

Wikfors GH, Smolowitz RM (1995) Experimental and histological studies of four life-history stages of the eastern oyster, Crassostrea virginica, exposed to a culture strain of the dinoflagellate Prorocentrum minimum. Biol Bull 188:313-328 